\title{
МАРИЈА ПОКРАЈАЦ
}

\section{ИНЖЕЬЕР ЈОВАН СМЕДЕРЕВАЦ (1854-1920)}

\begin{abstract}
САЖЕТАК:
Јован Смедеревац један је од инжењера који су крајем XIX и почетком XX века, након школовања у Бечу, значајној европској престоници, у српску архитектуру унели нови дух који је допринео процесу европеизације пре свега Београда, а потом и целе Србије. Циљ овог рада јесте да прошири сазнање везано за живот и значај дела инжењера Јована Смедеревца. Он је залагањем у оквиру сопственог архитектонског бироа, који је у време када је основан у Србији био новина, па потом у оквиру Београдске општине као члан многих одбора одговорних за питање модернизације Београда, и као члан Грађевинског удружења и Удружења српских инжењера и архитеката, допринео развоју Србије измучене ропством и ратовима. У то време у Србији је било тешко успоставити било какав континуитет, а камоли у изградњи, и тиме на крају допринео обогаћењу српске архитектонске историографије, али и историје индустријализације и европеизације Србије.
\end{abstract}

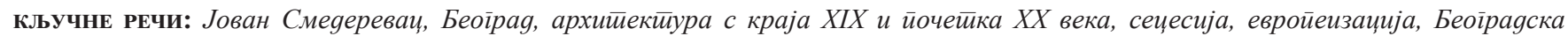

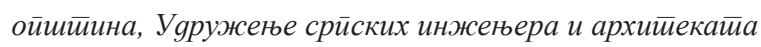

\section{ABSTRACT:}

Educated in Vienna, a significant European capital, Jovan Smederevac was one of the engineers who introduced a new spirit in Serbian architecture in late 19th and early 20th century, which initially contributed to the Europeanization of Belgrade, and later across the entire Serbia. The aim of this paper is to expand the knowledge about the life and significance of engineer Jovan Smederevac's work. His made a significant contribution towards Serbia's development working within his own architectural bureau, at the time of its establishment being quite a novelty in Serbia, and later on within Belgrade municipality as a member of committees responsible for the city's modernization, as well as a member of the Construction Association and the Association of Serbian Engineers and Architects. At the time, Serbia was exhausted upon undergoing occupation and wars, and it was difficult to achieve any continuity, especially in construction. Hence, Smederevac's work contributed to the enrichment of Serbian architectural historiography, as well as the history of industrialization and Europeanization of Serbia.

KEYwORDS: Jovan Smederevac, Belgrade, architecture in late 19th and early 20th century, Secession, Europeanization, Belgrade Municipality, Association of Serbian Engineers and Architects.

\section{Увод}

$\mathrm{J}$ ован Смедеревац (сл. 1) припада генерацији градитеља који су крајем XIX и почетком XX века допринели европеизацији како српске престонице, тако и других градова у Србији. Припадао је српској елити која је свој статус стекла, пре свега, образовањем на познатим европским универзитетима. ${ }^{1}$ Основну школу Смедеревац је завршио у Баваништу, месту у Банату где је рођен 11 . новембра 1854 . године, и где је живео у породици столара Ђорђа Смедеревца, који је по вероисповести био грчки православац. ${ }^{2}$ Иако неки извори наводе да је Реалку завршио у
Београду, ${ }^{3}$ према извештају са Техничког факултета у Бечу, где је студирао на катедри за цивилно инжењерство, Реалку је завршио у Панчеву. Томе у прилог говори и чињеница да у Историјском архиву у Панчеву постоји збирка породице Смедеревац, која подразумева само једну кутију, у којој данас не постоји документација везана за Јована Смедеревца, али на основу поменутог извештаја може се закључити да је реч управо о његовој породици. ${ }^{4}$ На Техничком факултету у Бечу студирао је од 1873. до 1878. године. Прве године, живео је у улици Gutenberggasse 21/1/6, од 1874. до 1875. 


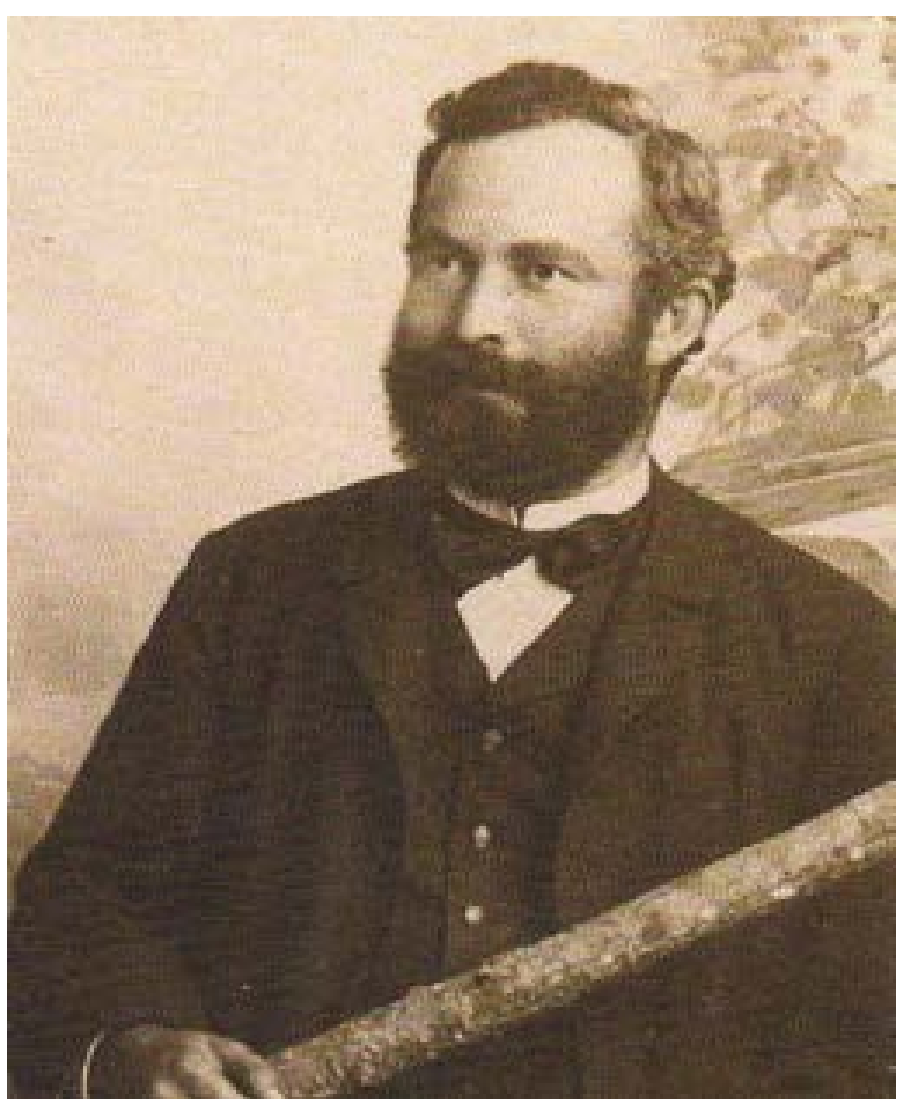

Сл. 1 / Фойоїрафија Јована Смеgеревиа (БурићЗамоло, Д. (2011), Граяитеељи Беоіраgа 1815-1914, Беоїpag: Музеј їpaga Беоїpaga).

живео је у улици Fleischmanngasse 13/28/4, а од 1876. до 1877. године у улици Engelgasse 9. Као студент је био ослобођен школарине, а од 1875. до 1878. године, примао је стипендију Српске православне цркве у Новом Саду, у износу од 500 форинти. ${ }^{5}$ Био је члан Српског ђачког друштва „Зора”, најзначајнијег удружења српске омладине у Бечу, основаног 1863. године. ${ }^{6}$ У оквиру овог удружења, које је подстицало дисциплину и истрајност српске омладине 7 , Смедеревац је као двадесетогодишњи студнет 1874. одржао предавање под називом „О обожавању сунца”. 8 Након завршених студија 1878. године, вероватно је неко време провео на студијском путовању, јер се у Србију враћа тек 1881. године. У Београду се, при државној служби, бавио инжењерско-предузимачким пословима, да би од 1893. године, отприлике у време када и предузимач-архитекта Милош Савчић, отворио приватни биро, где се бавио пројектовањем јавних и приватних зграда и финансијским пословима. ${ }^{9}$ У Панчеву се Јован Смедеревац оженио Милевом Ановић, 30. августа 1887. године. С њом је имао троје деце: Љубицу, која је још као дете умрла од туберкулозе, Ђуру и Загорку. ${ }^{10}$
Према подацима са Новог гробља, Јован Смедеревац је умро 18. априла 1920. године, а сахрањен је 19. априла 1920. године. Сахрану је обавила његова супруга Милева. За његово гробно место данас нема уплатиоца, што наводи на закључак да Јован Смедеревац нема живих потомака. ${ }^{11}$ Његова сурпуга Милева преминула је 17. марта 1931. године, а сахрањена је у породичној гробници у Панчеву. Сахранили су је ћерка Загорка и зет Милан Јаношевић. ${ }^{12}$

\section{Инжењерско-архитектонска делатност Јована Смедеревца}

У време кад се Јован Смедеревац формирао као стручњак у сфери цивилног инжењерства и архитектуpe, ${ }^{13}$ на архитектонској сцени у Европи још увек владају утицаји академизма на бази историцизма. На крају XIX и почетком XX века, долази до уплива нове уметности, која је у Паризу носила назив Ар-Нуво, у Минхену Југендстил, а у Бечу сецесија. Интернационални методи Ар-Нувоа, односно нове уметности, утврђени у делима белгијског архитекте Виктора Орте и бечког архитекте Ота Вагнера, пренети су на српску архитектонску сцену бојажљиво у виду облика и тема, кад је реч о кованој и штуко декорацији, каменим и керамо-пластичним украсима у виду флоралних, зооморфних и геометријских мотива, док је основа грађевина и даље остајала на бази симетричног и строгог академизма. ${ }^{14}$ Потребно је напоменути да нова уметност у српској архитектури није пронашла своје упориште због презасићености историзмом, него из потребе да српска архитектура иде, што је више могуће, руку под руку са европским архитектонским токовима. ${ }^{15}$ Поред Јована Смедеревца, носиоци Ар-Нувоа у српској архитектури су углавном школовани на београдској Великој школи, а своје усавршавање су настављали на академијама и техничким школама у Минхену, Бечу, Карлсруеу, Будимпешти и Прагу и на студијским путовањима по Европи. ${ }^{16}$ Међу 40 архитеката овог кова, поред Јована Смедеревца, издавајају се посебно: Виктор Азријел, Милан Антоновић, Никола Несторовић, Андра Стевановић, Данило Владисављевић, Стојан Тителбах, Бранко Таназевић, Димитрије Т. Леко, потом млађи Петар Бајаловић, Ђура Бајаловић, Петар Гачић, Јосиф Букавац, Владимир Поповић, Светозар Јовановић. ${ }^{17}$

Занимљиво је да су архитекти око 1880 . године називани инжењерима и налазимо их и у архитектонском и у инжењерском одељењу Министарства грађевина. ${ }^{18}$ Јован Смедеревац је већ од осамдесетих година био познат међу инжењерима, бавећи се углавном извођачким радовима како у Београду, тако и у 
унутрашњости земље. Један од првих његових подухвата по доласку у Србију, био је рад на изградњи пруге Београд-Ниш. ${ }^{19}$ У то време, отварање београдске железничке станице било је условљено одлукама Берлинског мировног уговора из 1878. године, након Српско-турског рата. По овом уговору су се српска влада и кнез Милан Обреновћ, обавезали да спроведу у дело Споразум о укључивању српске железнице у систем аустроугарских пруга. Ратовима економски ослабљена Србија, била је приморана да затражи помоћ страних концесионара, што је довело до склапања уговора са једним од париских акционарских друштава. Од 1880. до 1884. године, захваљујући пре свега финансијској и стручној помоћи страних инвестиција, Краљевина Србија добија прву железничку пругу ${ }^{20}$ која повезује градове Београд и Ниш, у дужини од 234,5 км. ${ }^{21}$ Великом подухвату инкорпорирања српских, у западне и источне саобраћајне мреже, су поред Јована Смедеревца, допринели и инжењер Васа Атанацковић, архитекта Драгутин Милутиновић и инжењер Светозар Зорић. Отварању железничке станице, као и тренутку поласка првог воза присуствовало је више од две стотине званица из целе Европе. Прво је 20. августа 1884. године, пругом до Земуна, на релацији Београд - Савски мост прошао дворски воз у ком су путовали краљ Милан и његова породица. Воз је био испраћен уз војну музику и прикладну церемонију. Три дана касније, кад је обављено свечано отварање железничке пруге Београд-Ниш, зграда Железничке станице била је окићена тробојкама и зеленилом. ${ }^{22}$

Поред учешћа на изградњи пруге Београд-Ниш, познато је да је Јован Смедеревац радио и на изградњи комплетне пруге Аранђеловац-Лајковац, ${ }^{23}$ изграђене 1908. ${ }^{24}$ Иако је после балканских ратова железничка мрежа у Србији била доста скромна, значајно је утицала на развој унутрашњег капиталистичког тржишта, и на размештај производних снага, што је довело до просперитета српске привреде. ${ }^{25}$

Када почетком XX века у Београду, почињу да се организују приватни бирои за извођење свих врста архитектонских и грађевинских послова, биро Јована Смедеревца почиње да добија на значају. ${ }^{26}$ Познато је да је крајем осамдесетих година XIX века подигао једну од зграда за потребе пиваре Бајлони на углу Скадарске и Цетињске улице. ${ }^{27}$ Наиме, Игњат Бајлони, због тешке економске ситуације претходног власника Јована Брабеца, откупљује производњу и сам плац на коме се пивара налазила 1888. године, и под именом „Игњат Бајлони и синови”, 29. фебруара исте године започиње са пиварском производњом. ${ }^{28}$ Пивара је након уласка у фирму „Игњат Бајлони и синови” предата на управу Јакову Бајлонију, ${ }^{29}$ који је убрзо откупио и околна имања чиме је проширен плац пиваре. Набављао је нову пиварску опрему из Аустроугарске и Немачке. Снабдевање главном сировином, водом, решено је тако што је изграђен сопствени водовод, којим се вода црпела из Дунава. У склопу пиваре изграђена је и сладара за производњу друге главне сировине, слада, док се хмељ морао увозити. До 1896. године је у изградњу и обнову пиварских зграда уложено 245.000 динара, у машине за производњу пива 129.000 динара, у покретни материјал и стоку 7.700 динара, и у набавку сировина 50.000 динара, што је све укупно износило 431.700 динара. ${ }^{30}$ Пивара је имала седам занатских радионица за разне потребе као што су: бачварска радионица, коларска, столарска, сарачка, ковачка, механичарска и електротехничка. ${ }^{31}$ У фабричком кругу становали су сви стручни мајстори и стално запослени радници, при чему је пивара имала шест станова за стручне мајсторе и десет соба са 110 лежаја за смештај радника. ${ }^{32}$

Судећи према данашњем изгледу, зграда коју је подигао Јован Смедеревац је двотрактног решења основе, са академизмом као стилском базом кад је реч о троделној хоризонталној и вертикалној подели фасаде, која је остварена уз помоћ подеоних венаца и јонских пиластера. Присутни су и елементи сецесије у виду украса од кованог гвожђа на балконима, декорацији прозора и улазних врата, као и камених украса у виду женских глава. Како није у потпуности сигурно која је била намена ове зграде, на основу изгледа и физиономије, може да се закључи да је служила за смештање радника и мајстора, и обављање административних послова за потребе пиваре.

Смедеревац је допринео развоју индустрије у Београду и учешћем у изградњи пруге која је повезивала Београдску кланицу са главном железничком станицома. Ова пруга изграђена је 1899. године, и повезивала је станицу Сточни трг са станицом Београд-Кланица, а одатле даље са главном београдском железничком станицом. Ова пруга је на захтев Кланичког друштва грађена упоредо са изградњом Београдске кланице, чије зграде су подигли архитекти Милош Савчић и Данило Владисављевић. Станица Београд-Кланица имала је велики економски значај за Србију. ${ }^{33}$ Градња Кланице на Дунаву започета је 1895. године према Закону о помагању кланичких предузећа из 1885. године, који је прописивао и изградњу одговарајућих железничких веза са овим погоном. Једноколосечна пруга која је пуштена у рад 1899. године ишла је од Железничке станице, уз саму обалу реке Саве, пружала се кроз 


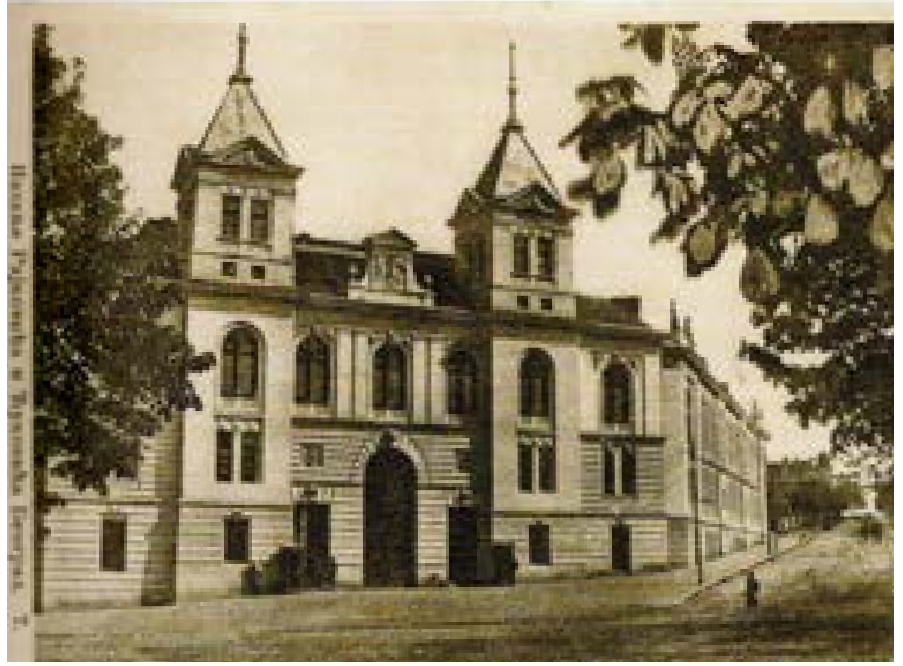

Сл. 2 / Разйлеgница Касарне VII йука Ресавске и Неманине улиие (Ђурић-Замоло, Д. (2011), Граяийељи Беоїраgа 1815-1914, Беоїpag: Музеј їpaga Беоїpaga)

пристаниште по савском кеју испред зграда са дућанима, па настављала око Доњег града, преко Јалије до Кланице. На тој прузи, која је временом добијала нове колосеке, била је отворена и железничка станица Кланица, касније, од 1936. године, Дунав станица. Кланичка пруга је била слепи колосек до изградње Панчевачког моста, када је допирала све до Баната. У међуратном периоду пруга је прерасла у индустријску пругу за опслуживање дунавске индустријске зоне. ${ }^{34}$

Као многи инжењери пред Први светски рат, и Смдеревац се бавио подизањем зграда јавне и стамбене намене. Већ 1894. године се наводи као предузимач грађевинар у „Трговачко-занатлијском шематизму Краљевине Србије”, што је значило да се ваћ тада његов приватни биро бавио извођењем свих врста грађевинских радова. ${ }^{35}$ Године 1895 . био је ангажован приликом изградње Касарне VII пука (сл. 2), на углу Немањине и Ресавске улице у Београду, према плановима архитекте Драгутина Ђорђевића. ${ }^{36}$

Јован Смедеревац је као предузимач био део Грађевинског савета Министарства грађевина 1898. године, ${ }^{37}$ а следећа зграда коју је подигао у Београду, и која се сматра његовим најбољим делом јесте кућа на углу Нушићеве и Македонске улице из 1901. године (сл. 3). ${ }^{38}$ Ова зграда је међу првима у Беграду на којој су присутни елементи нове уметности ${ }^{39}$ и која је представник интернационалног смера Ар-Нувоа у Београду. ${ }^{40}$ Реч је о једноспратници, академски, двотрактно решене основе засеченог угла. Према закључку о учешћу грађевинских инжењера у пројектима

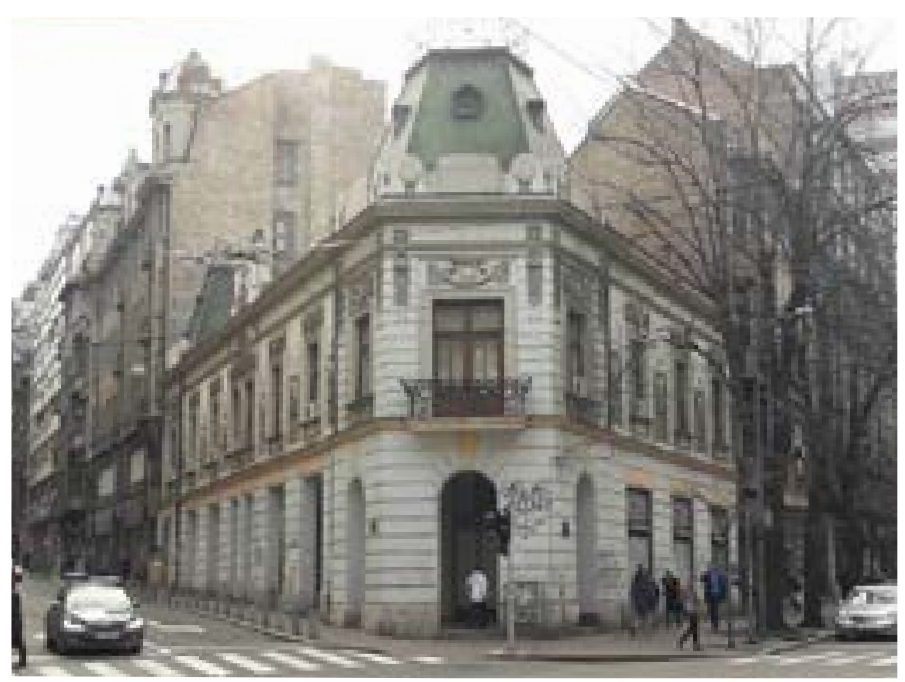

Сл. 3 / Фойоїрафија куће Јована Смеgеревца на уйлу Нушићеве и Макеgонске улице (лична колекиија)

стамбених зграда, Смедеревац није могао да пројектује фасаду ове зграде, мада је могуће да је био идејни творац орнаментике. ${ }^{41}$ Код зграде је, кад је реч о фасадама, наглашен управо угао због своје богате декорације. Фасада угла објекта решена је на оба спрата у ненаметљивој рустици при чему се у централном делу приземља налази полукружно завршен улаз, док је први спрат акцентован балконом израђеним од кованог гвожђа и отвором завршеним правоугаоним тимпаноном који је обогаћен декорацијом у виду волута и кружног украса у средини, а који су окружени акантусовим лишћем. Бочно од централног отвора и балкона, у висини тимпанона, налазила су се два украса у виду пауновог пера. Угао зграде је завршен куполом у облику зарубљене пирамиде, са окулусима на страницама, и која је надвишена оградицом од кованог гвожђа. Иста кула је поновљена на крају фасаде окренуте ка Нушићевој улици. Окулуси су данас заптивени док остали делови купола нису мењали своју физиономију. Сецесијска декорација у виду флоралних преплета, је поновљена и у тимпанонима прозора бочних фасада. Централни део фасаде у Нушићевој улици наглашен је декорисаном бифором у висини првог спрата и атиком изнад завршног венца. Данас су локали приземља угла нешто увученији у односу на остатак фасаде, па зграда има прозрачнији изглед. Ова грађевина је 1966. године проглашена за споменик културе, ${ }^{42}$ као дело значајног српског градитеља, издвајајући се у архитектури Београда по својој декоративности примењеној на свим слободним површинама, што је за време кад је по- 


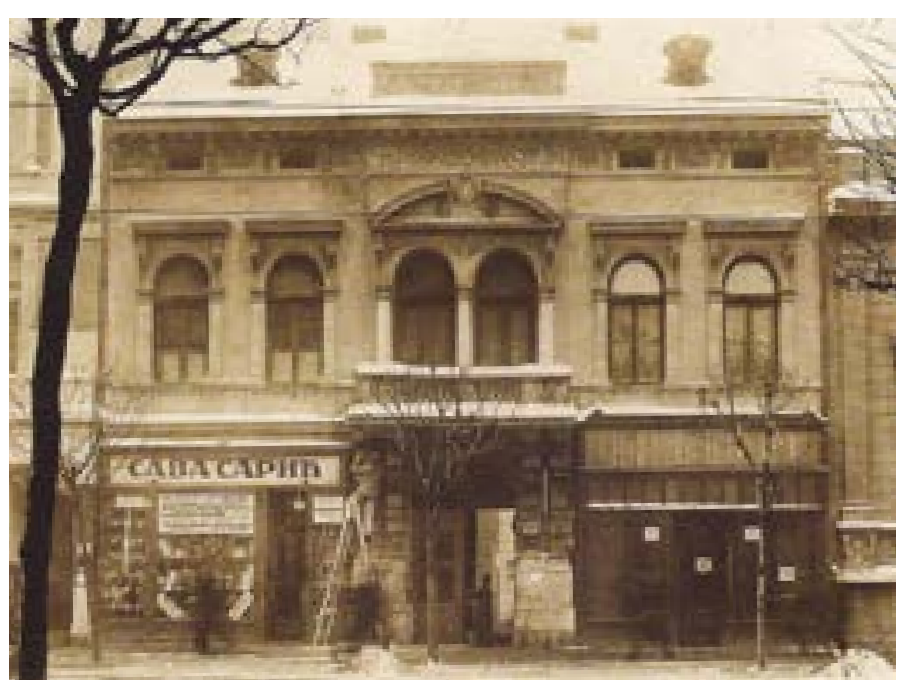

Сл. 4 / Фойоїрафија зіраяе на Теразијама број 36 (Ђурић-Замоло, Д. (2011), Граяииеељи Беоїраga 1815-1914, Беоїраg: Музеј їраgа Беoīpaga)

дигнута представљало почетак ослобађања од крутих правила академизма.

Познато је да је Јован Смедеревац већ 1902. године био члан Грађевинско предузимачког еснафа у Београду, ${ }^{43}$ а исте године је на збору одржаном у кафани „Код српског краља” изабран у привремену управу заједно са инжењерима Милошем Савчићем, Љубом Марковићем, Ђуром Николићем и Адолфом Штоком. Њихов задатак, као привремене управе, био је да заврше све претходне послове у року од три месеца, као што је на пример упис чланова до избора сталне управе. ${ }^{44}$ Такође је био члан Повлашћеног столарског акционарског друштва. Ово друштво је основано како би се бавило фабричком израдом и усавршавања израде столарских артикала свих врста, а посебно оних који су се увозили из иностранства. За покретање посла било је потребно да се сакупи капитал у износу од 500.000 динара, при чему је за остварење овог буџета било нужно прикупљање акција, где је свака акција износила 25 динара. Министар народне привреде одобрио је правила друштва 25. јануара 1902. године. Оснивачки одбор је након тога отворио упис акција и апеловао на све суграђане да се укључе у њихово прикупљање. Оснивачи Повлашћеног столарског акционарског друштва су, поред Јована Смедеревца, били: министар финансија Милован Маринковић, трговац Никола Спасић, воскар Трифун Ђорђевић, директор Трговачке банке Милош Туцаковић, архитекта Милош Савчић, професор Велике школе Мика Петровић, трговац Јефта Лаковић, трговац Витомир Марковић, аг-

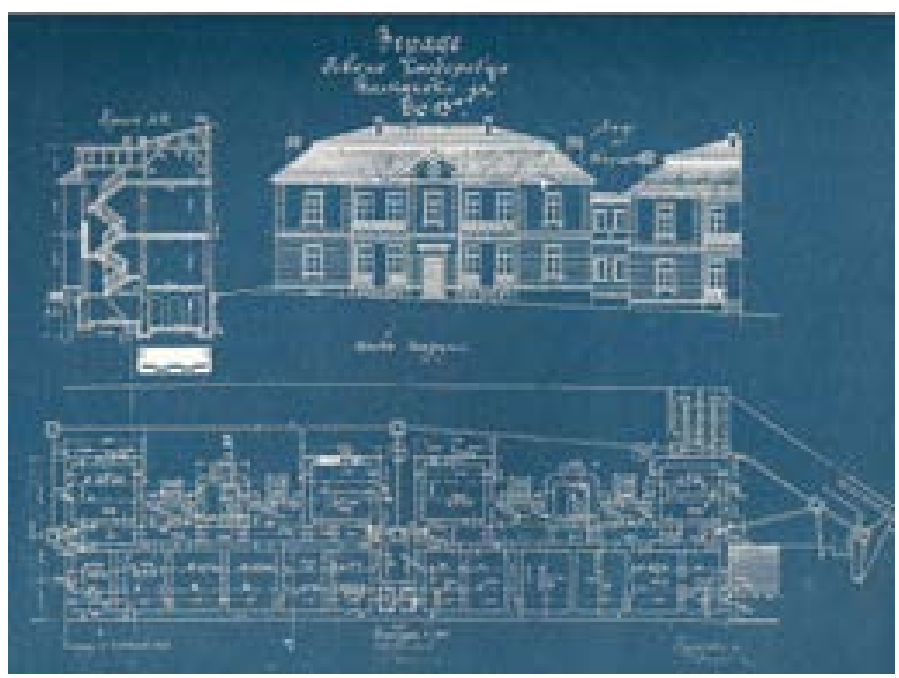

Сл. 5 / Основа йодрума, йойречної йресека и изйлеgа фасаgе зіраяе у Балканској улиии на броју 13 (Бурић-Замоло, Д. (1980), Беоїpag og 1898-1914, из архиве Грађевинскої оgбора, Беоїраg: Музеј їpaga Беоїpaga)

ент Краљевског Румунског Бродарства Манојло Торбица, адвокат Живојин Симић, инжењер Бродарског друштва, инжењер Светолик Поповић, хотелијер Светозар Боторић, лимар Јован Сремац, тапетар Фердинанд Квирини, столар Јован Крика, бравар Петар Палић, вештачки столар Светозар Злајковић. ${ }^{45}$

Смедеревац је 1905. године подигао две зграде које су биле повезане пасажом. Једна се налазила у Балканској улици на броју 13, док друга постоји и данас и налази се на Теразијама на броју 36 (сл. 4). Планови за обе зграде чувају се у архиви Музеја града Београда. ${ }^{46}$ Зграда на Теразијама је вероватно подигнута већ деведесетих година XIX века, а преправке су рађене 1905. године. ${ }^{47}$ Оно што се види из документације јесте да је у Смедеревчевом поседу био велики плац под зградом на Теразијама број 36 који се налазио поред плаца трговца Алексе Крсмановића, где је подигнута кућа по пројекту архитекте Јована Илкића. ${ }^{48}$ Оба земљишта су имала излаз на Балканску улицу, при чему је површина земљишта у власништву Јована Смедереваца износила три метра.

Зграда окренута ка Теразијама је једноспратна, са уличном фасадом решеном у академском маниру, ${ }^{49}$ са рустично обрађеним приземљем у чијем централном делу се налази полукружно завршен отвор који води у пасаж. Са бочне стране отвора налазе се застакљене површине излога локала, трговинске намене. Централни део спрата наглашен је балконом са балустрадом и бифором завршеном прекинутим сегментним тимпаноном. Бочно од бифоре налазе се по 
два полукружно завршена прозора. Завршни венац чини богата зооморфна рељефна декорација. Изнад завршног венца, у централном делу, издиже се једноставна правоугаона атика, са каменим барокним вазама на оба краја. Кров су красила два окулуса са обе стране уличне фасаде зграде. Ова зграда постоји и данас, у готово изворном стању, као типичан представник академског начина обликовања у архитектури Београда с краја ХIX века. На сличан начин, у необарокном стилу, била је решена и узана фасада према Балканској улици (сл. 5) где су се налазили само богато декорисана улазна капија и један прозор изнад ње. Већи део земљишта је био покривен стамбеним објектима чије су фасаде биле окренуте према дворишту. Зграде су биле једноспратне или приземне у зависност од пада терена. Данас се на овом месту налази модерна вишеспратница, која не приличи простору на ком је подигнута својом спратношћу и модерним дизајном. Није познато да ли је пројектовао још коју зграду, јер како је наведено, више се бавио извођачким радовима како у Београд, тако и у другим градовима Србије. У архитектонској историографији се наводи да је подигао мост на реци Ђунис, као и мост на Нишави. ${ }^{50}$

Јована Смедеревца су око 1910. године за члана Занатске коморе изабрали предузимачи. Био је један од првих грађевинара са „протоколисаном радњом” по Закону о радњама из 1910. године. Пре Закона о радњама за сваку занатлијску браншу постојали су еснафи, када су и грађевинари имали свој Предузимачки еснаф коме су припадали и зидаро-тесачки мајстори. Ступањем на снагу овог закона, формирана је Занатска комора као врховна инстанца занатлијских организација. ${ }^{51}$ Након доношења Закона о радњама, Занатска комора, у чијој је управи као представник грађевинара и зантлија био Јован Смедеревац, на његов предлог је редиговала одлуку о делокругу грађевинара предузимача код извођења високих градњи, коју је одобрио министар народне привреде и која гласи: „Предузимач-грађевинар предузима целу грађевину а поједине даје у израду мајсторима тих заната, а као стручно лице у грађењу зграде он руководи свим пословима на згради; он ради детаље за поједине занате (нацрте и описе) и уопште упућује и надзирава израду грађевине. Према томе предузимач-грађевинар предузима и изводи израду целе грађевине." 52 Оваква одлука наводи на закључак да почетком XX века, занатски и грађевински послови све више добијају на значају, те да се домен делатности зантлија и грађевинара проширује.

\section{Рад у Београдској општини}

Пред крај XIX века, Београд се све више ширио и модернизовао. У том периоду долази до развоја варошке индустрије, на шта је значајно утицала промена начина живота становништва кад је реч о односу према стилу одевања, забави, исхрани и свеукупним навикама, које су биле махом преузете из Западне Европе. Све ове промене су условиле и довеле до модернизације заната у Београду. ${ }^{53}$ Београдска општина је предузимала обимне радове у циљу уређења града, што је између осталог подразумевало и подизања нивоа комуналне опремљености по угледу на велике европске престонице. ${ }^{54}$ Од великог значаја за модернизацију српске престонице било је и отварање прве електричне централе 1892 . године, ${ }^{55}$ чиме започиње процес електрификације Србије, а од 1893. године и Београда. ${ }^{56}$ Урбанизација и регулација улица у престоници је крајем XIX века била све учесталија. Ток регулације и изградње је у својим путописима из деведесетих година XIX века забележио аустроугарски путописац Феликс Каниц на следећи начин: „Изграђена је читава мрежа праволинијских и изванредно поплочаних улица, са електричним осветљењем, са дивним државним зградама и лепим приватним кућама, мрежа која испресецана дрворедима, скверовима и трамвајским линијама, већ читаву деценију достојно ставља Београд у ред млађих европских престоница и привлачи већ многе странце да се у њему трајно настане." 57

Европеизацији престонице, својим залагањем, допринео је и инжењер Јован Смедеревац. Он је био ангажован од стране Београдске општине за решавање питања која су се тицала инжењерско-предузимачких радова у српској престоници. Тако је 1902. године био један од одборника у Комсији за ревизију регулационог плана који се односио на пресецања Видинске улице према Дунаву. Приликом састанка Комисије, Смедеревац је изнео да сматра да је велики проблем што се „регулациони план мења како се коме свиди и да примедбе других одборника, Светозара Јанковића и Јована Ђурића, који су се побунили што се регулација вароши не врши по утврђеном реду, за овај случај нису утемељене". Такође је било речи о отварању нове улице која би повезивала Таковску са Гундулићевом улицом, при чему је виши инжењер железничке дирекције Коста Живковић приложио своје целокупно имање у Таковској улици општини на откуп, како би се омогућило рушење и отварања нове улице. Тада је Јован Смедеревац уз одборнике Косту Ризанића и Милана Димића ушао у ужи одбор који је решио питање отку- 
па и рушења. ${ }^{58}$ Један од предлога Јована Смедеревца приликом редовног заседања општинског одбора, био је измена Члана 13. Грађевинског закона за варош Београд. Том приликом Смедеревац наводи следеће: „Познато је да су и грађани сопственици имања у Београду до доношења грађевинског закона за варош Београд плаћали за израђену калдрму пред њиховим имањем на целој дужини од три фата ка улици. Закон по коме су грађани имали ову дужност донео је кнез Михаило који је провевши дуже време на страни користио то време проучавајући разне установе на страни, па је знање које је тим стекао употребио на добро српског народа па и Београда. 1896. не зна се са каквих разлога донесена је одредба у грађевинском закону за варош Београд а измене у Члану 13. истог по којој израда калдрме и тротоара заједно са планирањем земљишта пада на терет општинске касе. Том одредбом онемогућен је готово сваки рад на калдрмисању варошких улица јер 10.000 динара колико општина ставља у свој буџет није довољно ни за одржавање калдрме а то ли за израду нове калдрме. Док су грађани по ранијем закону плаћали за израђену калдрму пред њиховим имањем за три фата а општина израђивала на терет своје касе у осталом калдрму у улицама. Урадило се доста, а то што је урађено види се, а ако остане садашње стање неће се моћи готово ништа урадити. Са наведених разлога предлаже да Општински одбор реши да се умоли господин министар грађевина да изволе предложити Народном представништву у првом његовом сазиву да изволе у Члан 13. Грађевинског закона за варош Београд учинити измену тако да друга алинеја поменутог члана гласи: У улицама које нису калярмисане а укаже се йойреба gа се калярмишу gужни су сойстввениии имања їgе се калgрма іра-

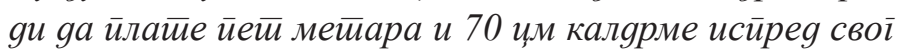
имања на иуелој яужини истиої а ка улици у найреg оg йейої. Среgину йлаћа ойшишина. Гgе већ йостиоји калgрма а нивелисана је улища и калярму итреба нову саіраgити и илаћа сваки сойсиввеник само израяу йройоара са ивичним каменом. Прейрес и оирравке на калярми и

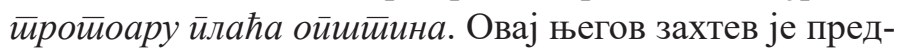
седништво усвојило. ${ }^{59}$

Смедеревац се залагао да Трамвајско друштво, по угледу на организацију у Бечу, прилагоди ред вожње трамваја интересима публике Народног позоришта и да трамваји буду пуштени у промет пре и после позоришних представа. ${ }^{60}$ Такође се залагао за израду таблица са називима улица и нумерисање кућа. ${ }^{61}$ Био је у грађевинском, економском одељењу Општине Београд заједно са Адолфом Штоком и Живојином Перићем као и у сталном колтролном одбору за изградњу Новог гробља. ${ }^{62}$ Приликом израде ограде и шкарпирања земље на Калемегданском брегу, заједно са архитектом Миланом Капетановићем, добио је задатак да извиди шта је узрок одроњавању брега и да заједно са управницима грађевинског одељења и општинског водовода предложи начин на који би брег могао да се осигура од даљег одроњавања. ${ }^{63}$ Приликом ревизије регулационог плана 1902. године, био је члан комисије у коју су ушли и председник општине Милован Маринковић, као и одборници Коста Главинић, Милан Петровић и шеф грађевинског одељења. Задатак ове комисије је био проучавање варошке регулације како би се урадила ревизија досадашњег регулационог плана. ${ }^{64}$

Јован Смедеревац је својим залагањем и радом у Београдској општини значајно допринео да предратни Београд доживи свој полет и стане раме уз раме са већим европским престоницама.

\section{Активност у Удружењу српских инжењера и архитеката}

Од великог значаја за развој архитектуре и урбанизма Србије и Београда било је оснивање Удружења српских инжењера и архитеката, 1890. године. Јован Смедеревац је важио за уваженог члана овог удружења, заузимајући значајне позиције у одборима који су се бавили уређењем Београда по европским стандардима.

Смедеревац је добио овлашћење од Удружења да 1895 . године потпише резолуцију везану за побуну српских инжењера, јер је Општина израду плана за канализацију и водовода, без конкурса, доделила страним инжењерима. ${ }^{65}$ Такође, био је изабран у ужи одбор за поправку оштећених мостова. ${ }^{66}$ Један од његових задатака у Удружењу био је и утврђивање нивоа влаге у појединим кућама и становима. ${ }^{67}$ Заједно са колегама инжењерима, учествовао је у организованом протесту против одлуке Српске краљевске академије да зграду за њене потребе подигну страни архитекти. ${ }^{68}$ Наводи ce 1918. године, као редовни члан Удружења српских инжењера и архитеката, са звањем привредног инжењера и грађевинара. ${ }^{69}$

Једна од значајних иницијатива Удружења српских инжењера и архитеката била је и израда генералног плана Београда, коју је путем конкурса Удружење покренуло још почетком XX века. У резолуцији из 1912. године, Удружење је донело одлуку да би за осмишљавање генералног плана регулације Београда требало расписати „свеславенску утакмицу”. Тада је апел Удружења остао без одазива, тако да су активности расписивања конкурса настављене у фебруару 1919. године, 
након два балканска и Првог светског рата. Предложено је да се распише међународни конкурс, али да се учешће забрани државама непријатељима из рата. Ипак, Одбор је донео одлуку, 17. априла 1919. године, да се што пре изради план за уређење Београда путем интернационалног конкурса и то без ограничења на право учешћа. Убрзо је формиран Одбор за израду програма за стечај о добијању плана за уређење и проширење Београда. ${ }^{70}$ Председник одбора је био Михаило Марјановић, тадашњи председник Београдске општине, а потпредседници инжењер Филип Трифуновић, инспектор Министарства грађевина и Драгутин Ђорђевић, архитекта и професор Универзитета. Поред Јована Смедеревца, чланови Одбора били су: Андра Јовановић, Аца Петровић, Бранко Таназевић, Веселин Лучић, Воја Ђорђевић, Воја Кујунџић, Душан Пантић, Драгиша Мирковић, Ђорђе Радојковић, Лука Ћеловић и други. Записнике са састанка Одбора водио је општински архитекта Зарије Марковић, који је навео да је Министарство саобраћаја каснило са делегирањем представника, као и да су са састанка најчешће изостајали представници комора и петорица општинских одборника. Завршетак рада Одбора на изради програма пратила је и смена градске управе, због чега је на чело Одбора дошао Коста Јованвић, новоименовани вршилац дужности председника општине. ${ }^{71}$ Након много расправе, коначно је комплетиран текст програма који је архитекта Драгутин Ђорђевић, на седници Одбора одржаној 6. децембра 1919. године, представио и који су чланови усвојили без примедби. ${ }^{72}$ Реферат који је саставио Ђорђевић, Општински одбор је усвојио и упутио га Министарству грађевина на одобрење, које је тражило мишљење и оцену Главног техничког савета. Око питања да ли будући план треба да се односи и на будуће делове вароши Београд или само на постојеће, јавило се доста опречних ставова, па је Општински одбор на седници одржаној 17. маја 1921. донео одлуку да међународни конкурс буде основа за израду плана, уређење и проширење Београда, односно определио се за израду „ширег плана за даљу будућност". ${ }^{73}$

Од 1919. године Удружење српских инжењера и архитеката постаје Удружење југословенских инжењера и архитеката. Још у то време се јавила идеја за подизање зграде која би била седиште Дома југословенских инжењера и архитеката. Јован Смедеревац је био члан Оснивачког одбора за послове организације и финан- сија за подизање зграде, уз Косту Главинића, Драгутина Маслаћа, Миливоја Смиљанића, Јанка Шафарика, Зарија Марковића, Нестора Манојловића, Владимира Поповића, Клементија Букавца и Душана Божића, док је за архитектуру зграде био задужен Клуб архитеката Секције Београд. ${ }^{74}$ Ипак, изградња је пролонгирана, па је стога зграда подигнута тек између 1933. и 1935. године у Улици Кнеза Милоша на броју 7 у Београду, чинећи значајан наратив идеологије југословенства у то време. ${ }^{75}$ Удружење, прво српских, па потом југословенских инжењера и архитеката, са својим званичним гласилом „Техничким листом”, представљало је значајну повезницу кад је реч о заједничком деловању архитеката и инжењера у бившој Југославији.

\section{Закључак}

У време када је Србија доживљавала трансформацију у виду европеизације, од великог значаја су били инжењери и архитекти који су се крајем XIX века вратили са школовања у иностранству и у српску ахитектуру донели дух нових стремљења и идеја која се тичу употребе материјала, различитих стилова и допуњавања онога што је чинило строги академизам којег су се придржавали архитекти од средине XIX века, као узвишеног стила увезеног из Европе. Инжењер Јован Смедеревац је својим деловањем, како у сопственом бироу, тако и у јавним институцијама, допринео да идеје нове уметности заживе и на српској архитектонској сцени. Залагао се за оснивање Удружења грађевинара као и за њихово уједињење. Захваљујући својој стручности и залагању у оквиру Београдске општине, успевао је да заузме значајне позиције кад је реч о одлукама везаним за питања ширења и модернизовања Београдске вароши. Допринео је повезивању српских градова у XIX веку, али и повезивању Србије са другим градовима у Европи, као и развоју српске привреде, радећи на изградњи првих железничких пруга. Стога је, инжењер Јован Смедеревац, иако увек помињан у прегледима који се тичу архитектонске историографије краја XIX и почетка XX века, заслужио да се његовом лику и делу посвети посебна пажња, што је био циљ овог рада.

\section{Марија К. Покрајац}

историчар уметности

marijak059@gmail.com. 


\section{НАПОМЕНЕ}

1] Трговчевић 2003: 48

2] Према архиви Техничког факултета у Бечу, према речима Mmag. Alexandra Weiser.

3] Ђурић-Замоло 201: 301 .

4] Према речима историчара-архивисте Милице Пејчиновић, Историјски архив Панчево.

5] Према архиви Техничког факултета у Бечу, према речима Mmag. Alexandra Weiser.

6] Rohrbach 2017: 22.

7] Истио

8] Ђурић-Замоло 2011: 301; Ротер Благојевић 2006: 391.

9] Истио.

10] Загорка је била удата за Милана Јаношевића и за време Првог Светског рата живела је у Женеви у „Pension demoiselle Clarins". Beogradske novine, 11. februar 1916: 4.

11] Јован Смедеревац је сахрањен на парцели број 9, гробница број 20 у трећем реду. (Према речима историчара уметности Виолете Обреновић, Ново гробље, Београд).

12] Правgа, 18. март 1931: 13.

13] Потреба за стручњацима који би градили јавне објекте, али и израђивали машине, први пут се јавила у Енглеској, где Џон Смитон (John Smeaton) уводи појам „цивилног инжењера" (eng. civil engineer) 1771. године, а од 1827. године образују се школе специјализоване за цивилне инжењере. Од самог настанка термин „инжењер” означава врсту стручњака и мајстора који је за своја умећа користио техничка знања. Он је био стручњак који је успевао да споји теорију с праксом (Више о томе у: Трговчевић 2003: 156)

14] Кадијевић 2004: 58-60; Ротер Благојевић 2006: 389.

15] Шкаламера 1985: 7.

16] Исйо: 9.

17] Исйо: 10; Ротер Благојевић 1997: 155.

18] Несторовић 2006: 264.

19] Ђурић-Замоло 2011: 301; Стојановић 1912: 32.

2о] Божичковић 1972: 317.

21] Стојановић 1977: 253.

22] Bogunović: 2005.

23] Ђурић-Замоло 2011: 303; Несторовић 2006: 268.

24] Вучо 1955: 223.

25] Вучо 1955: 223.

26] Ђурић-Замоло 2011: 301; Несторовић 2006: 268; Стојановић 1912: 32.

27] Несторовић 2006: 268 .

28] Лукић 2010: 123.

29] Јаков Бајлони је био познати угледни београдски трговац и привредник. Он је у раној младости изучио пинтерски занат у некој од пивара у Бечу. У Београду је са оцем и браћом радио у гостионици, био је један од иницијатора формирања Првог српског пиварског акционарског друштва и један од његових акционара. Био је члан Управног одбора Народне банке као и један од оснивача Српског бродарског друштва, а неко време је био и члан Управе државних монопола. Лукић: 2010, 124.

3о] Лукић: 2010, 124.

31] Вучо 1976: 100.

32] Истио: 102.

33] Михајлов 2011: 97.

34] Vuksanović-Macura 2015: 47.

35] Христић 1905: 45.

36] Зграда Касарне VII је представник зреле фазе академизма у Србији, што је последица Ђорђевићевог усавршавања у Карлсруеу, где је прихватио став професора Јозефа Друма да се стил грађевине одређује према њеној намени. Реч је о пространој грађевини, дугих фронтона, са широко засеченим углом, са сутереном, приземљем и два спрата. Фасада приземља и првог спрата је рустично обрађена, док је други спрат истакнут двобојним материјалом, са бифорама под заједничким луковима, што је одлика архитектуре ране ренесансе. Широка фасада на самом углу наглашена је монументалним полукружно завршеним улазом, који је имао колску и пешачку намену. Ова фасада била је надвишена атиком завршеном са троугластим тимпаноном, испод ког је у рељефу био изведен грб Краљевине Србије у виду двоглавог орла са штитом са крстом изеђу оцила, док су бочни декоративни елементи атике била два сферно обликована украса. Фасада угла са улазом, фланкирана је бочним кулама, чије су фасаде наглашене бифорама на сваком спрату, и које су, надвисујући пету фасаду завршене пирамидалним куполама, што одаје утисак војног утврђења, односно намене саме зграде. Утиску војне зграде доприносе и рељефни украси у виду штитова и оклопа. Зграда је у време изградње била ниска у односу на своју габаритност, па је већу складност добила када јој је 1926. године дозидан и трећи спрат од стране архитекте Министарства војног Блаже Вукићевића. Тада је зграда припојена Министарству војном, а до тад је била једна од првих модерних касарни у Србији. Ђурић-Замоло 2011: 303; Несторовић 2006: 346; Кадијевић 2005: 332.

37] Државни календар Краљевине Србије 1898: 43.

38] Несторовић 2006: 268; Кадијевић 2004: 58-60; Шкаламеpa 1985: 10; Ђурић-Замоло 2011: 302; Кадијевић, 2005: 345; Manević 1972: 16.

39] Manević 1972: 16.

40] Кадијевић 2004: 58-60.

41] Ђурић-Замоло 2011: 302.

42] Решење Завода за заштиту споменика културе града Београда бр. 660/1 од 15. 7. 1966.

43] Оснивање еснафа је од 1882. године одобравало Министарство народне привреде, а непосредну контролу над сваким еснафом вршила је надлежна полицијска власт. Више о томе у: Вучо 1955: 196.

44] Мале новине, 4. јануар 1902: 3.

45] Мале новине, 10. март 1903.

46] План за преправку куће Јована Смедеревца у некадашњој Улици Краља Милана 42, данас Теразије 26, са основама подрума и приземља, изгледом уличне фасаде, и три детаља у размери 1:100, са печатом Грађевинског одбора о прегледу планова са бр. 65 од 8. фебруара 1905. чува се, под сигнатуром Ур. 11653. Планови за 
зграду у Балканској 13 чувају се под следећим сигнатурама: ситуациони план основе приземља и првог спрата у размери 1:200 Ур. 11654; план пресека са изгледом дворишне фасаде у размери $1: 100$, Ур. 11654; план основе првог спрата у размери 1:100, Ур. 11656 и план основе подрума, пресека и изгледа главне фасаде дугачке дворишне зграде у размери 1:100, Ур. 11657. Сви планови су из 1905. године, па је зграда вероватно тада и подигнута

47] Ђурић-Замоло 2011: 303.

48] Више о томе у: Димитријевић-Марковић 2012: 4.

49] Минић 1960: 455.

50] Стојановић 1912: 32; Ђурић-Замоло 201: 302.

51] Беоіраяске ойшиинске новине, 5, јуни 1935: 400.

52] Правgа, 2. март 1934: 6.

53] Vučo 1974: 82.

54] Ротер Благојевић 2003: 111; Несторовић 1955: 248.

55] Више о томе у: Вучо: 1977.

56] Vučo 1974: 91.

57] Каниц 1967: 239.

58] Беоірраяске ойииииске новине, 22. септембар 1902: 255.

59] Беоїраяске ойшииинске новине, 20. октобар 1902: 1. 6о] Беоїраяске ойшииинске новине, 27. октобар 1902: 1.

61] Беоіраяске ойшииинске новине, 17. новембар 1902: 286.

62] Беоіраяске ойшиинске новине, 22. фебруар 1903: 56.

63] Беоіраяске ойшииинске новине, 27. април 1903: 1.

64] Беоіраяске ойшиинске новине, 12. мај 1902: 156.

65] Беоіраяске оишииинске новине, 2. август 1895: 133.

66] Технички лист: Орган Удружења српских инжењера и архитеката, 1903: 4.

67] Срспки Технички лист: Орган Удружења српских инжењера и архитеката, 1905: 3 .

68] Срспки Технички лист: Орган Удружења српских инжењера и архитеката, 2. фебруар 1914: 35.

69] Срспки Технички лист: Орган Удружења српских инжењера и архитеката, 15. јун 1918: 14.

7o] Vuksanović-Macura 2015: 53.

71] Vuksanović-Macura 2015: 54.

72] Ист̄о: 55.

73] Више о томе у: Вуксановић-Мацура 2013: 106-107.

74] Више о томе у: Игњатовић 2006: 91.

75] Исиио.

\section{ЛИТЕРАТУРА}

Београдске вести (1902), Мале новине, 4. јануар: 3.

Bogunović, S. (2005), Arhitektonska encikopedija Beograda XIX u XX veka tom I, Beograd: Beogradska knjiga.

Божичковић, В. (1972), Београд као саобраћајни чвор, Гоgишъак ìpaga Беоїpaga XIX (Београд): 317-330.

Вуксановић-Мацура, 3. (2013), Престионица Карађорђевића: Емил Хопе и Ото Шентал на конкурсу за Генерални план Београда,

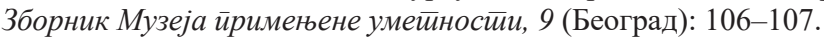

Vuksanović-Macura, Z. (2015), San o gradu: Međunarodni konkurs za urbanističko uređenje Beograda 192-1922, Beograd: Orion art.

Вучо, Н. (1955), Привреgна исйорија Србије gо Првої свейской

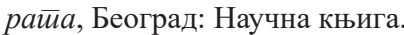

Vučo, N.(1974), Pogled na industrijsku revolucije u Srbiji u XIX veku, Acta-Historico-oeconomica Iugoslaviae vol.I (Zagreb): 79-97.

Вучо, Н. (1976), Бајлонова пивара у Скадарлији 1880-1941, Гоgишъак їраgа Беоїраgа ХХIII (Београд): 93-106.

Вучо, Н. (1977), Београдска електрична централа (1892-1940), Гоgишъак їpaga Беоіраgа ХXIV (Београд): 165-179.

Грађевинско економско одељење општине Београд (1903), Беоіраяске ойшииинске новине, 22. фебруар: 56.

Димитријевић-Марковић, С. (2012), Крсмановићева кућа на Теразијама, Београд: Завод за заштиту споменика културе града Београда.

Ђурић-Замоло, Д. (1980), Беоїраg og 1898-1914, из архиве Грађевинскої оgбора, Београд: Музеј града Београда.

Ђурић-Замоло, Д. (2011), Граяииеељи Беоїраgа 1815-1914, Бео- град: Музеј града Београда.

Игњатовић, А. (2006), Дом Удружења југословенских инжењера и архитеката у Београду, Наслеђе VII (Београда): 87-118.

Кадијевић, А. (2004), Два тока Српског архитектонског Ар-Нувоа: интернационални и национални, Наслеђе V (Београд): 53-70.

Кадијевић, А. (2005), Естиеииика архииекейуре акаяемизма, Београд: Грађевинска књига.

Каниц, Ф. (1967), Краљевина Србија и срӣски нароg; Беоі̄pag у gевейнаесом веку, Београд: Музеј града Београда.

Комисија за ревизију регулационог плана (1902), Беоїраgске оишииинске новине, 22. септембар: 255.

Краљевско Ср. Академија Наука и Уметности (1914), Срсйки Тех-

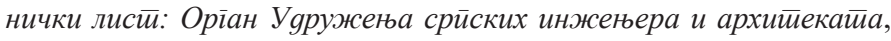
година XXV: 35.

Лукић, Н. (2010), Парна пивара Игњат Бајлони и синови $1888-$ 1946, Наслеће XVI (Београд): 123-138.

Ljubica Sv. Stevanović gospodi Stevi Aćimoviću i Jovi Jovičiću u Ženevi (1916), Beogradske novine, 11. februar: 4.

Manević, Z. (1972), Novija srpska arhitektura, Srpska arhitektura 1900-1970, Beograd: Muzej savremene umetnosti.

Министарство грађевина (1898), Државни каленgар Краљевине Србије, 143.

Минић, О. (1960), Језгро Београда, Гоgишњак їраgа Беоїраgа VII (Београд): 441-472.

Михајлов, С. (2011), Настанак и развој индустријске зоне на дес- 
ној обали Дунава у Београду од краја 19. до средине 20. века, $H$ слеђе XII (Београд): 91-116.

Несторовић, Б. (1955), Еволуција београдског стана, Гоgишъак ipaga Беоїpaga II (Београд): 247-270.

Несторовић, Б. (1974), Преглед споменика архитектуре у Србији XIX века, Саойииеюь а Х (Београд): 141-169

Несторовић, Б. (2006), Архииеккӣура Србије у ХIX веку, Београд: Арт Прес .

Одговор Удружења грађевинара: Сукоб инжењера и грађевинара, став Инжењерске коморе (1934), Правgа, 2. март: 6.

Позив на упис акција повлашћеног столарског акционарског Друштва (1903), Мале новине, 10. март: 5.

Рад одбора општинског (1895), Беоїраяске оимииинске новине, 2. август: 133 .

Рад одбора општинског (1902), Беоіраяске ойииинске новине, 12. мај: 156.

Рад одбора општинског (1902), Беоіраяске ойшиинске новине, 20. октобар: 1 .

Рад општинског одбора (1902), Беоіраяске ойшииинске новине, 27. октобар: 1.

Рад одбора општинског (1902), Беоїраяске ойшииинске новине, 17. новембар: 286.

Рад општинског одбора (1903), Беоїраяске ойшииинске новине, 27. април: 1.

Рад Удружења (1903), Срйски Технички лисии: Орїан Удружења

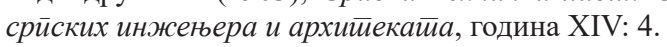

Рад Удружења (1905), Срсйки Технички лисй: Орїан Уяружења

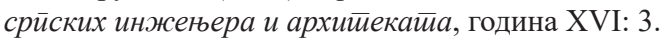

Ротер Благојевић, М. (1997): Настава архитектуре на вишим и високошколским установама у Београду током XIX и почетком XX века: утицај страних и домаћих градитеља, Гоgишњак іраgа Беоìpaga XLIV (Београд): 125-168.

Ротер Благојевић, М. (2003), Архитектура грађевина јавних намена изграђених у Београду од 1868. до 1900. године (први део), Apхийектиура и урбанизам 12/13 (Београд): 111.

Ротер Благојевић, М. (2006), Сйамбена архийекӣура Беоі̄paga y XIX и йочейком XX века, Београд: Орион Арт.

Rohrbach, W. (2017), Kaiser Franz Joseph I und die Serben 18481908, Istorija XX veka XXXV 1/2017 (Beograd): 9-37.

Списак редовних чланова Удружења српских инжењера и архитеката на дан 10. јун 1918. године (1918), Срсйки Технички листи: Opіан Уяружењ а срйских инжењера и архииеккайа, 15. јун: 14.

Стојановић, С. (1912), Ойис їрађевинских раgова и израgа са сликама, Београд: Штампарија С. Хоровца.

Стојановић, Б. (1977), Београдски железнички чвор, Гоgишњак ippaga Беоїpaga XXIV (Београд): 253-275.

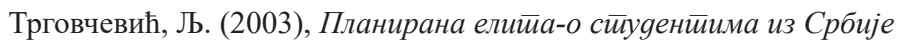
на евройским универзииетиима у XIX веку, Београд: Историјски институт.

Удружење градитеља-грађевинара (1935), Беоїраяске ойшишиске новине, 5. јуни: 400.

Христић, С. (1905), Предузимачи грађевина, Тріоовачко-занайлијски шемайизам Краљевине Србије V (Београд) : 45.

Читуља (1931), Правgа, 18. март: 13.

Шкаламера, Ж. (1985), Сецесија у српској архитектури, Зборник Нарояноі музеја ХІІ-2 ( Београд): 7-13.

\section{Summary: MARIJA POKRAJAC}

\section{ENGINEER JOVAN SMEDEREVAC (1854-1920)}

Engineer Jovan Smederevac was part of the generation of architects who made a significant contribution to the Europeanization of Serbia at the end of the 19th and the beginning of the 20th century, and above all Belgrade, at the time experiencing liberation from the Ottoman influences and starting to gain the outlines of a modern European capital. Smederevac was born and attended elementary school in Bavanište in Banat, later moving to Pančevo and attending the Real Gymnasium, and further on to Vienna where he studied civil engineering at Politehnikum. He was a member of one of the most important Serbian youth associations "Zora" in Vienna. He returned to Serbia in 1881 and started working in the Belgrade municipality. In this period he took part in the construction of the Belgrade-Niš railway line, whose establishment made a significant contribution to the development of transport network in Serbia, connecting the two major cities. He was in charge of the construction of Aranđelovac-Lajkovac railway line, the Belgrade Slaughterhouse railway line, as well as the construction and repair of numerous bridges. An engineer by profession, he was primarily engaged in construction and contracting jobs, but he was also recognized as an architect, constructing his own house on the corner of Nušićeva and Makedonska streets in Belgrade - one of the first examples of a more liberal use of Art Nouveau decoration on a building conceived in academism style. He also constructed the building 
in 36 Terazije street, with a passageway linking it with the building in 13 Balkanska street, later demolished to make way for a modern multi-storey building. In cooperation with architect Dragutin Đorđević, he constructed the military Barracks of VII Regiment in Belgrade, being in charge of contractor works, as well as one of the buildings on the lot of Bajloni brewery. As part of his work in Belgrade Municipality, he advocated the issues of Belgrade's expansion, the zoning and construction of new streets. He dealt with financial matters related to the municipal budget. In late 19th century he instated his own architectural bureau, at the time being quite a rarity, and even luxury. Within his bureau, he mostly engaged in construction and contracting works. As a member of the Association of Serbian Engineers and Architects, he was a member of board, advocating and promoting the idea of Belgrade's modernization. Appreciating all of these roles, the work of engineer Jovan Smederevac has been strongly significant for the development of the Serbian capital, and Serbia overall, and he should therefore be studied with higher attention and focus, which served as the main goal of this paper.

\section{Illustrations}

Fig. 1 A photograph of Jovan Smederevac (Source: Đurić-Zamolo, D. (2011), Graditelji Beograda 1815-1914, Beograd: Muzej grada Beograda)

Fig. 2 1.Postcard of the VII Regiment Barracks, the corner of Resavska and Nemanjina streets (Source: Đurić-Zamolo, D. (2011), Graditelji Beograda 1815-1914, Beograd: Muzej grada Beograda)

Fig. 3 A photograph of Jovana Smederevac's house on the corner of Nušićeva and Makedonska streets (Source: personal collection)

Fig. 4 A photograph of the building in 36 Terazije street (Source: Đurić-Zamolo, D. (2011), Graditelji Beograda 1815-1914, Beograd: Muzej grada Beograda)

Fig. 5 Floor plan of the basement, cross-section view and the façade of the building in 13 Balkanska street (Đurić-Zamolo, D. (1980), Beograd od 1898-1914- iz arhive Građevinskog odbora, Beograd: Muzej grada Beograda) 